\title{
The Impact of Direct Foreign Investment on Unemployment in Jordan
}

\author{
Mohammad Haroun Eid Al Amarat \\ Albalqa' Applied University, Ma'an University College, Ma'an, Jordan \\ Email: amarat.univdrbalqa@gmail.com
}

Received 28 April 2016; accepted 25 June 2016; published 29 June 2016

Copyright (C) 2016 by author and Scientific Research Publishing Inc.

This work is licensed under the Creative Commons Attribution International License (CC BY). http://creativecommons.org/licenses/by/4.0/

(c) (i) Open Access

\begin{abstract}
This study aimed at recognizing the size of direct foreign investment in Jordan and its impact on the rate of unemployment in Jordan. It also aimed at recognizing the constraints against the foreign investment. The study concludes that the low levels of these investments are attributed to the lack of regulating legislations that encourage foreign investment in Jordan. The study recommends the development of services and infrastructures; besides, the Jordanian concerned departments should prepare and disseminate the information on investment opportunities in Jordan.
\end{abstract}

\section{Keywords}

Foreign Investment, Unemployment, Jordan

\section{Introduction}

The competition on attracting the foreign investment and increasing the local investment around the world has increased vastly during the last decade. As a consequence to the important changes that occurred in the frameworks of economic exchange among countries, these countries intended to conduct vast improvement in its economic and legislative structures to encourage foreign investors to localize their investment around the world. Most countries deregulated the constraints against the movement of capitals to benefit the huge flows of direct foreign investment.

Since Jordan suffers high rates of unemployment, it expects the increase of labor supply in the future in the light of current rate of population growth as well as the labor force of refugees, and the plans of government to improve or retain the standards of living of citizens.

The challenges require the increase of capital commulation as possible; especially there is a gap between saving and investing. Therefore, the flows of direct foreign investment to Jordan can support the local, but insufficient, investment. 
Many researchers studied the nature of direct foreign investment in several countries, including Jordan [1]. Our study will focus on the size of foreign investment in Jordan and challenges that will encounter due to its importance to the national economy.

\section{Questions of Study}

This study will answer the following questions:

1) What is the size of direct foreign investment in Jordan?

2) Is there any relationship between the size of foreign investment and decrease of unemployment rate in Jordan?

3) What are the obstacles that hinder the momentum of foreign investment in Jordan?

\section{Objectives of the Study}

The study aims at achieving the following objectives:

1) Recognize the size of foreign investment in Jordan.

2) Recognize the impact of this investment on the total volume of investment.

3) Determine the obstacles that encounter the foreign investment in Jordan.

\section{The Concept of Direct Foreign Investment}

The direct foreign investments are the investments that are owned and directed by foreign investors through their full or partial ownership of projects that enable them to manage its affairs. The direct foreign investment has dual characteristics: first the foreign investor owns the economic enterprise inside the host country and the investor owns the project totally or partially [2].

Through distinction between direct and indirect foreign investment we can differentiate the aspects of controlling and dominating the foreign project. When the investor controls or dominates his project abroad, the investment will be called direct foreign investment. If such investor doesn't dominate the foreign project his investment will be called indirect.

The direct foreign investment represents the first type, which is a simple form of foreign investment. This type is legislated and regulated by the developing countries because these countries seek greatly to attract such type of investment in order to seize the sources of production [3].

Since this type of investment let foreign investors control and dominate actively their projects to achieve their interests, then they will be able to transfer the profits and advantages of these projects outside the said country, as well as dominating the production and marketing efforts of these projects [3]. Many countries depended on the direct foreign investment to sustain their developmental efforts, such as USA and some advances countries [4].

\section{Importance of Direct Foreign Investment to the Developing Countries}

The importance of direct foreign investment stems from its attributes through creating new jobs, technology transfer, and providing advanced administrative knowledge to the said countries, besides assisting these countries to join the membership of exporting countries. The direct foreign investment enhances the economic development through international production in the countries that lack sufficient capitals.

The direct foreign investment is also important to the investors where they get diversification in production activity and be near the natural resources. There are some considerations that encourage developing countries to attract foreign investment:

- Direct foreign investment helps developing countries to support and fund the local capital to overcome the lack of capitals and deficit of trade balance, through flow of necessary capitals to create new projects.

- Many developing countries suffer a sharp shortage of national saving necessary for funding the development and investments, so they get assistance of the foreign investment.

- The use of appropriate management in the direct foreign investment helps economy to encounter and adapt to the external economic shocks through maintaining steady volumes of foreign capitals and long term economic growth.

- The direct foreign investment can contribute to the development of exporting such as what happen in China 
at present.

- The direct foreign investment can contribute to the development through the research activities in the concerned countries, such as the case of China with Microsoft.

- The direct foreign investment can help enhancing the technology transfer that will increase the quality of skills and open new channels for marketing and exporting.

\section{Aspects of Foreign Investment}

There are two aspects of foreign investments.

1) Direct Foreign Investment in the Traditional Sectors:

This type works in production of natural resources that host countries need, through MNC companies, such as minerals, phosphates, potash and oil.

2) Direct Foreign Investment in the Least Cost Production or in the Markets of High Demand on the Production and Skilled Labor Force:

This type seeks to find places of available advantages in order to achieve high levels of profits, besides enabling the host countries to increase its ability and capacity to export and support its balance of trade.

Therefore, the direct foreign investment can assist the host countries through technology transfer, knowledge and skills transfer; create more job opportunities besides activating and enhancing the competition in the local market for some seekers.

If the host country earned benefits of these investments, these will improve productivity in the local market and support the export and economic development. In the phase of economic development, and according to the international commitments of the developing countries, they will not be able to inter the competition market locally and internationally.

Therefore, the direct foreign investment is very important to the developing countries to overcome the economic difficulties and improve its standards so as to reach the international market [5].

\section{Drivers for Direct Foreign Investment in Development Countries}

There are different taxonomies for these drives based upon the goals of such investment. The major goal of the direct foreign investment in the markets with natural resources is to exploit the competitive advantage of these countries besides gaining the low wages labor force or skills. Another type of the direct foreign investment is represented by finding new markets abroad especially in the countries importing the products of the advanced foreign country that will invest there [6].

The available and suitable climate for investing in the host countries means in general all legal, economic, political and social facilities represented by the infrastructure ready for investing. These factors affect the responsiveness of foreign capitals to localization.

\subsection{The Economic Factors That Include}

\subsubsection{Nature of Economic and Commercial Activity}

The commercial and economic activity has a great role in persuading the foreign investors to invest in the host countries. The foreign investors make efforts to remedy the lost or weak markets by new and blooming markets abroad.

\subsubsection{Increase Profits}

The main goal of any investor is growth and sustainability of projects through achieving more profits under their management. To achieve this goal many foreign investors find it is better to search for new markets with low cost of production, storage, labor force and marketing, to gain the competitive advantages over their rivals.

\subsubsection{Desire for Rapid Growth}

Earning revenues alone will not be sufficient to attract foreign investment, so those investors will seek to develop commercial exploitation of the markets [6]. The inability of national markets to achieve the goals of growth and expansion leads to foreign investments abroad [7]. 


\subsubsection{Reduction the Risks of Dependence on One Economic Market}

The foreign investors, in general, makes effort to diversify their investments in several markets and countries to reduce the impacts of negative shocks of economic crises which any country or market may encounter. Therefore, most foreign global companies tend to open branches in several markets to balance the contradicted impacts of economic crisis.

\subsubsection{Grasp the Educational and Technical Knowledge}

The technological advancement and sophisticated technologies contribute to attracting more direct foreign investment. The developing countries will not gain such knowledge without the participation of the advanced countries, where some type of collaboration should be created and established between the developing and developed countries. This collaboration will be implemented through $\mathrm{R} \& \mathrm{D}$ contracts then production with cooperation of companies in the developed countries.

\subsection{Legal Factors}

The legal factors let foreign investors satisfied of legal protection that will enable them to invest without concerns of sudden changes that affect their investments.

\subsection{Socio-Political Factors}

The political stability is an essential factor in making decisions of investing abroad. The foreign investors will not risk transfer their capitals and expertise abroad if they are not satisfied that political conditions there are good and stable [8]. The stable status will increase the opportunities for transfer and movement of investments and capital freely and easily.

The preferences of consumers in the host countries in the favor of national products will encourage foreign investors to move their capitals abroad to establish production projects in the host countries [9].

\section{Obstacles against the Direct Foreign Investment in Jordan}

1) Bureaucracy and multiple contradicted legislations that regulate the investment besides the references that investors should deal with create backward and affect negatively the investment environment [10].

2) Unavailable qualified managerial skills that fit the nature of investments planned. The trained and skilled labor force in Jordan prefer to find another places such as Gulf States which in turn lead to lack of skilled labor force in Jordan that can handle the new projects. Such dilemma is called "The Brain Drainage".

3) Unavailable environment that is characterized by economic security and stability so as the economic activities can be sustainable to attract more investments locally and globally .

4) Instability in the region affects negatively the foreign investment in Jordan due to the constraints of importation from Europe and exportation to the neighbor countries [11].

\section{Results}

1) Jordan didn't exploit the periods of high flow of investment to build a powerful industrial and economic base while the Jordanian economy continued in fluctuating upon the external conditions.

2) Despite the relative rise of investment and growth rates, it was not accompanied by a decrease in the rates of unemployment. This can be attributed to the concentration of foreign investments in specific sectors in Amman and absence of value added of these investments.

3) The direct foreign investment concentrates on establishing new projects or expanding present projects. These projects can't classify in the short term which will be reflected on the stability of relative direct foreign investment in the times of crisis.

4) Despite the little foreign investments in Jordan, these investments didn't contribute to development of local communities and support the public institutions outside Amman.

\section{Recommendations}

1) Provide more benefits facilities and incentives to attract foreign investments based on scientific approaches 
besides implementation of these investments to match the national interests.

2) Develop the logistic services and infrastructure of transportation to increase the efficiency of local products and secure its competitiveness in the external markets.

3) Eliminate or reduce the administrative constraints that hinder the trade exchange between Jordan and its partners.

4) Departments of investment encouragement should make studies about the opportunities for the foreign investment in Jordan and make campaigns to grasp these opportunities abroad.

5) Establish an advisory board for the Ministry of Industry and Commerce in Jordan to assist in planning the entire economic issues of Jordan and unifying the referrals that supervise the process of investment besides simplification of procedures for new foreign investments.

\section{References}

[1] Almohtasib, B.M. (2009) The Impact of Direct Foreign Investment on the Economic Growth of Jordan (1990-2006). J. Dirasat, 36.

[2] Alzahawi, F.H.S. (1984) Joint Enterprises According to the Law of Investment.A Doctoral Dissertation, Faculty of Law, University of Cairo, Cairo, p. 65.

[3] Alsayed, A. (1990) The Taxation Treatment of Foreign Investments. Dar Alnahda, Cairo, Egypt, p. 6.

[4] Abdulazeez, S.M. (1988) New Approaches of Funding the Economic Development. Mo'assast Shabab Aljami’ah, Alexandria, p. 421.

[5] Mohammad, N.H. (1992) The Economic Reform and Challenges of Development. 321.

[6] Alsamerai, D.M. (2006) Foreign Investment, Constraints and Legal Guarantees. Center for African Unity Studies, 86-89.

[7] Mohammad, N.E. (2010) The Impact of Foreign Direct Investment on the Future of Local Arab Investment: Analytical Metric Study for Some Gulf States during 1992-2010. p. 42.

[8] Saeed, M.S. (1986) Multi National Companies (MNC, s) and the Future of National Phenomenon. A'alam Alma'rifah, Kuwait, 28-29.

[9] Mudafar, A. (1985) The Nature of International Economic Base within the Present International Order. Dar Alnahda, Cairo, p. 12.

[10] Alesawi, I.H. (1976) The Realism of Expectation of Foreign Investment Flow and Its Contribution to Development of Egypt. A Paper Presented in the 1st Annual Conference of Egyptian Economists, Cairo, 25-27 March 1976, 128-129.

[11] www.aljazeera.net

Submit or recommend next manuscript to SCIRP and we will provide best service for you:

Accepting pre-submission inquiries through Email, Facebook, Linkedin, Twitter, etc

A wide selection of journals (inclusive of 9 subjects, more than 200 journals)

Providing a 24-hour high-quality service

User-friendly online submission system

Fair and swift peer-review system

Efficient typesetting and proofreading procedure

Display of the result of downloads and visits, as well as the number of cited articles

Maximum dissemination of your research work

Submit your manuscript at: http://papersubmission.scirp.org/ 